\title{
Detection of Cholera Toxin-Producing Vibrio cholerae in Phytoplankton from Santubong and Samariang Estuaries
}

\author{
LESLEY MAURICE BILUNG*, MINTRA PROMMANI ETRIAM, AHMAD SYATIR \\ TAHAR, TENG SING TUNG \& KASING APUN
}

\author{
Faculty of Resource Science and Technology, Universiti Malaysia Sarawak, 94300 Kota Samarahan, \\ Sarawak, Malaysia \\ *Corresponding author: mblesley@unimas.my \\ Received: 11 February $2019 \quad$ Accepted: 25 April $2019 \quad$ Published: 30 June 2019
}

\begin{abstract}
Many cholera outbreaks worldwide were associated with cholera toxin-producing Vibrio cholerae. The bacteria are ubiquitous in aquatic environment, whilst phytoplankton is associated with adaptation of the Vibrio species. This study was conducted to detect cholera toxin-producing Vibrio cholerae, and to determine association of the selected water physicochemical parameters with the number of the bacteria. In this study, a total of ten phytoplankton samples were collected at Santubong and Samariang Estuaries in Kuching, Sarawak. Water physicochemical parameters (temperature, $\mathrm{pH}$ and salinity) were recorded. Vibrio bacteria were cultivated on thiosulfate citrate bile-salts sucrose selective agar and analysed for cholera toxin-producing Vibrio cholerae using polymerase chain reaction by targeting $c t x \mathrm{~A}$ gene that encodes for virulence cholera enterotoxin subunit $\mathrm{A}$. The result revealed that a range of $1.0 \times 10^{7}-8.0 \times 10^{7} \mathrm{CFU} / \mathrm{ml}$ of yellow colonies growing on the thiosulfate citrate bile-salts sucrose agars. Inversely, no samples were positive with cholera toxin-producing Vibrio cholerae. The physicochemical parameters at Samariang Estuary were more associated with the number of bacteria in the samples compared to Santubong Estuary.
\end{abstract}

Keywords: cholera toxin-producing, ctxA gene, Vibrio cholerae

Copyright: This is an open access article distributed under the terms of the CC-BY-NC-SA (Creative Commons Attribution-NonCommercial-ShareAlike 4.0 International License) which permits unrestricted use, distribution, and reproduction in any medium, for non-commercial purposes, provided the original work of the author(s) is properly cited.

\section{INTRODUCTION}

Vibrio species is gram-negative bacteria, rodcurved shaped, halophile, non-spore forming, autochthonous living in marine and estuaries. The bacteria thrive in saline aquatic environments, that either be free in water or attached to animate surface like phytoplankton or zooplankton (Cavallo \& Stabili, 2002). The presence of Vibrio bacteria in the environment is influenced by different ecological parameters such as temperature, salinity, nutrient, and concentration of zooplankton and phytoplankton (Alam et al., 2003). Vibrio cholerae is one of the common species causing infection. In past record, cholera outbreaks occurred in Miri and Northern Division in Sarawak, Malaysia from November 1997 to April 1998 were due to the contaminated water supplies (Vincent et al., 2015).

Phytoplankton is responsible as natural reservoirs for Vibrio bacteria especially $V$. cholera. Furthermore, phytoplankton blooms can promote the increase in Vibrio spp. density (Huq et al., 2012). Direct influence of phytoplankton with growth of Vibrio is explained as the number of different phytoplankton species that can contribute to the growth of Vibrio (Peterson et al., 2010). Human risk from this event exists where the presence of Vibrio spp. in water and phytoplankton will lead to accumulation of Vibrio in the shellfish after filter feeding process (Huq et al., 2012).

Cholera toxin (CT) is one of critical virulence factors involved in enteropathogenicity by certain strains of the species (Radu et al., 2002). This toxin is strong heatlabile and encoded by $\operatorname{ctx} A$ gene. It was first discovered by Koch in 1884 (Broeck et al., 2007). On the other hand, O1 and 0139 serogroups are the only two $V$. cholerae serogroups critical for worldwide outbreaks. Other strains have been reported causing infections but being deemed as rare and trivial (Reidl \& Klose, 2002). Pathogenicity of $V$. cholerae is influenced by several virulence factors including potent enterotoxin (CT) (Sharma \& Chaturvedi, 2009), which is also carried by O1 and O139 groups (Dutta et al., 2013). Nonetheless, other non-O1 and non-139 strains may also produce cholera toxin during infection. Clinical manifestations of 
cholera infection includes massive excretion of ricewater stool that can amount to over ten litres a day (Broeck et al., 2007). Despite frequent of such reports in Sarawak, to the best of our knowledge this is the first study on the occurrence of $V$. cholerae in phytoplankton samples in the state. This preliminary study was conducted as to detect the presence of cholera toxin-producing $V$. cholerae in phytoplankton and to determine the association between physical parameters and the presence of $V$. cholerae.

\section{MATERIALS AND METHODS}

\section{Background of the Study}

Two estuaries in Sarawak were studied namely Santubong (1'117'50" N 110'19'34' E) and Samariang (1'36’32”N 110¹9’37” E) (Figure 1).

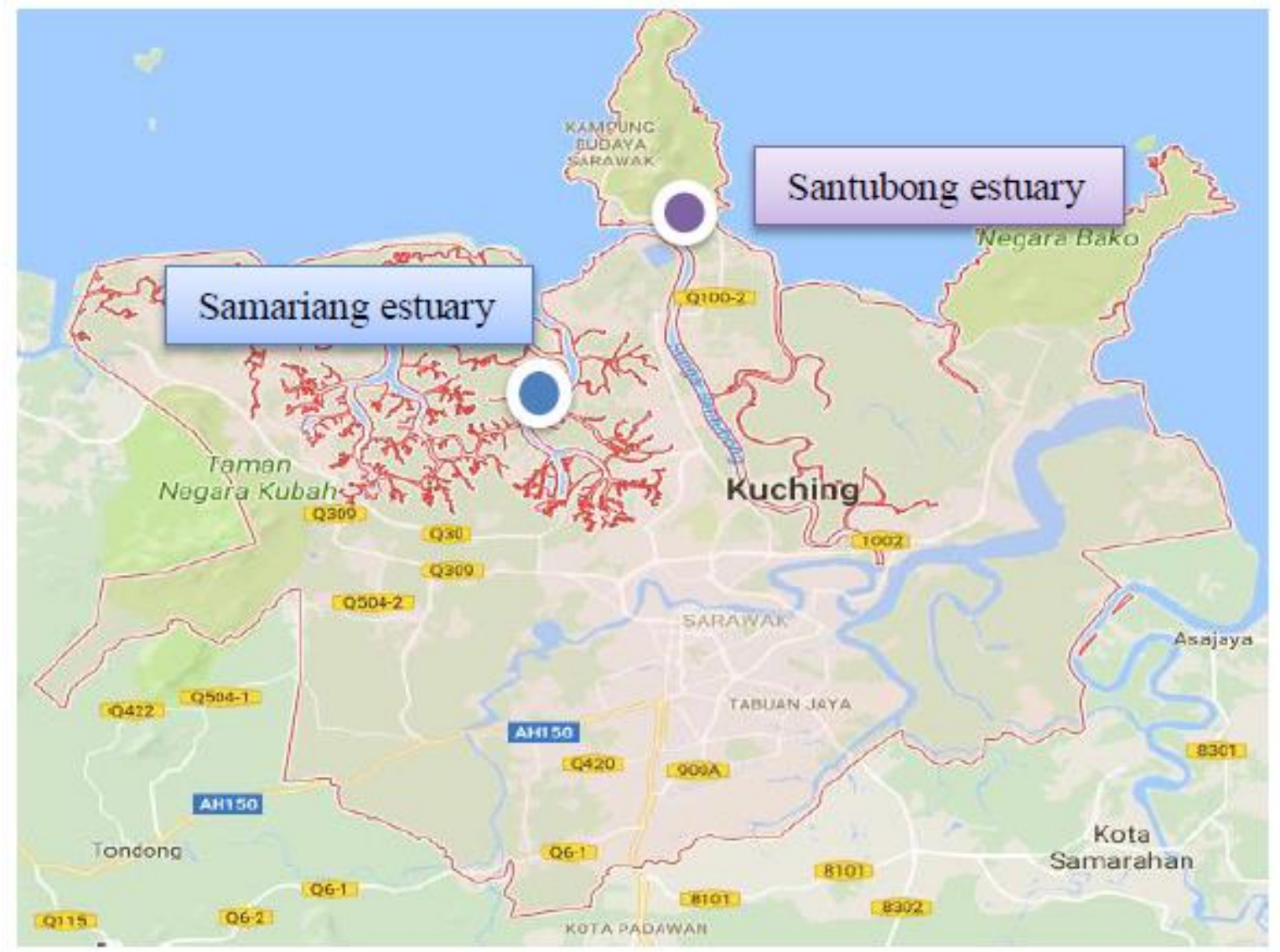

Figure 1. A map of Kuching, Sarawak showing the location of sampling sites in Santubong and Samariang Estuaries where phytoplankton samples were collected.

The geographical location of Santubong Estuary is located near to Damai Beach, whilst Samariang Estuary is located upstream of Samariang Estuary (Batang Salak). Furthermore, in these selected estuaries, the phytoplankton samples from Santubong sampling site were associated with sea water while the phytoplankton samples from Samariang sampling site were associated with brackish water. Areas of Santubong are local tourism places that are surrounded with resorts, whereas areas of Samariang Estuary are surrounded with mangrove forests that represent a habitat for aquatic living and several shrimp and fish cage cultures for protein source demands.

\section{Phytoplankton Collection and Water Physicochemical Parameter Assessment}

Phytoplankton sample collection was conducted as described by Tuney and Maroulakis (2014). Surface water samples were collected using a plankton net (10- $\mu \mathrm{m}$ mesh size). The sampling was conducted from November 2017 until January 2018 with a total of ten plankton samples were collected (500 $\mathrm{ml}$ each). The samples were stored in an ice box and were transported to Molecular Microbiology Laboratory at Universiti Malaysia Sarawak for further analysis. Besides, the selected water physicochemical parameters (i.e. $\mathrm{pH}$, temperature 
and salinity) were measured in-situ using a $\mathrm{pH}$ meter (Hanna Instrument, USA) to measure $\mathrm{pH}$ and temperature, and a hand refractometer (Agato, Japan) to measure salinity.

\section{Sample Processing}

The sample processing procedure was conducted as described by Huq et al. (2012). All samples were concentrated through filtration by using polycarbonate membrane filter $(0.45 \mu \mathrm{m}$ pore size; $47 \mathrm{~mm})$. The trapped phytoplankton on the membrane filter were washed with $25 \mathrm{ml}$ of sterile $1 \times$ phosphate buffer solution in $50 \mathrm{ml}$ of centrifuge tube before being vortexed. Next, $1 \mathrm{ml}$ of the sample was transferred into $25 \mathrm{ml}$ of alkaline peptone water (1\% peptone; $1 \% \mathrm{NaCl} ; \mathrm{pH} \mathrm{8.6)}$ and was incubated $24 \mathrm{~h}$ at $35^{\circ} \mathrm{C}$.

\section{Enumeration of Bacteria Using Spread Plate Method}

A five-tube serial dilution was conducted in Falcon tube containing $9 \mathrm{ml}$ of PBS. Afterwards, $100 \mu \mathrm{l}$ of each dilution solution was spread plated on thiosulfate citrate bilesalts sucrose (TCBS) agar (Oxoid, Canada) using a sterile hockey stick and the agars were incubated at $35{ }^{\circ} \mathrm{C}$ for $24 \mathrm{~h}$. Yellow colonies on TCBS agar were counted and expressed in colony forming unit (CFU) per millilitre of sample. This was calculated using Eq. 1. The bacteria isolates were used for subsequent analysis of bacteria identification.

$\mathrm{CFU} / \mathrm{ml}=\frac{\text { no of colonies } x \text { dilution factor }}{\text { volume of culture plate }}$ Eq. 1

\section{Identification of Bacteria via Gram Staining} The bacteria isolates were identified by morphological test via Gram staining. Gram staining procedure was conducted according to the Gram staining protocol (Smith \& Hussey, 2005).

The heated-fixed bacteria smear was subjected to crystal violet, iodine solution, alcohol or decolorizing agent and safranin respectively. The slide then was observed under light microscope at both $400 \times$ and $1000 \times$ with oil immersion.

\section{DNA Extraction and Polymerase Chain Reaction}

The boil cell method was conducted based on Bilung $e t$ al. (2005) with some modifications. Afterwards, the extracted DNA was used in the subsequent PCR assay for detecting $V$. cholerae by targeting the $c t x A$ gene. This procedure was in accordance to the method by Nandi $e t$ al. (2000) with some modifications. The PCR assay was conducted in $25 \mu \mathrm{l}$ final volume, containing $5.0 \mu \mathrm{l}$ of $5 \times$ Green GoTaq reaction buffer (Promega, USA), $0.3 \mu \mathrm{l}$ of $5 \mathrm{U}$ Taq DNA polymerase, $2.0 \mu \mathrm{l}$ of $25 \mathrm{mM}$ magnesium chloride, $1.0 \mu \mathrm{l}$ of $10 \mathrm{mM}$ deoxynucleotide triphosphates, $1.0 \mu \mathrm{l}$ of each $10 \mathrm{pmol} / \mu \mathrm{l} c t x A$ primer, 0.3 $\mu \mathrm{l}$ of $5 \mathrm{U} / \mu \mathrm{l} \mathrm{GoTaq}$ DNA polymerase (Promega, USA), 5.0 $\mu \mathrm{l}$ DNA template and $9.7 \mu \mathrm{l}$ distilled water. Details of the primers used is shown in Table 1.

The amplification reaction was run in a DNA thermal cycler (Perkin Elmer, USA) with a cycle of initial denaturation at $94{ }^{\circ} \mathrm{C}$ for $3 \mathrm{~min}, 35$ cycles each of denaturation at $94{ }^{\circ} \mathrm{C}$ for $1 \mathrm{~min}$, annealing at $60^{\circ} \mathrm{C}$ for 1 min, extension at $72{ }^{\circ} \mathrm{C}$ for $2 \mathrm{~min}$, and a cycle of final extension at $72{ }^{\circ} \mathrm{C}$ for $5 \mathrm{~min}$. DNA of $V$. cholerae was used as positive control, whilst distilled water was used as negative control.

\section{Agarose Gel Electrophoresis}

The PCR products were resolved by electrophoresis in $1.5 \%$ agarose gel. A $1 \mathrm{~kb}$ molecular weight DNA ladder was used in each reaction. The electrophoresis was run in $1 \times$ TBE buffer with a constant voltage of $90 \mathrm{~V}$ for 1 $\mathrm{h}$. The gel was stained with ethidium bromide for $20 \mathrm{~min}$ and visualised using transmitted ultraviolet illumination (Vilber Lourmat).

Table 1. Details of $\operatorname{ctxA}$ gene for detection of $V$. cholerae.

\begin{tabular}{ccccc}
\hline $\begin{array}{c}\text { Target } \\
\text { gene }\end{array}$ & Primer & Sequences (5'-3') & $\begin{array}{c}\text { Amplicon } \\
\text { size }(\mathrm{bp})\end{array}$ & Sources \\
\hline \multirow{2}{*}{ FtxA } & Forward: $c t x \mathrm{~A}-F$ & CTCAGACGGGATTTGTTAGGCACG & 302 & $\begin{array}{c}\text { Nandi } e t \\
\text { al. }(2000)\end{array}$ \\
\hline
\end{tabular}




\section{RESULTS}

\section{Bacterial Enumeration and PCR assay}

Enumeration of yellow colonies growing on the TCBS agar revealed that the number of bacteria in the phytoplankton samples from Samariang Estuary $\left(1.0 \times 10^{7}-8.0 \times 10^{7} \mathrm{CFU} / \mathrm{ml}\right)$ was higher than from
Santubong Estuary $\left(1.5 \times 10^{7}-4.0 \times 10^{7} \mathrm{CFU} / \mathrm{ml}\right)$ as shown in Table 2. Whilst, PCR analysis targeting the virulence cholera enterotoxin subunit A (ctxA) gene found that no samples of phytoplankton from both localities were positive with pathogenic strains of $V$. cholerae in phytoplankton samples as displayed in Table 2, Figures 2 and 3.

Table 2. Results of the spread plating and PCR assay for the phytoplankton samples

\begin{tabular}{cccc}
\hline & \multicolumn{3}{c}{ Santubong Estuary } \\
\hline Sampling date & Sample & $\begin{array}{c}\text { Colony forming unit }(\mathrm{CFU} / \mathrm{ml}) \text { of } \\
\text { yellow colonies }\end{array}$ & PCR assay \\
\hline $16 / 11 / 2017$ & A1 & $1.2 \times 10^{7}$ & Negative \\
$30 / 11 / 2017$ & A2 & $2.8 \times 10^{7}$ & Negative \\
$14 / 12 / 2017$ & A3 & $3.4 \times 10^{7}$ & Negative \\
$28 / 12 / 2017$ & A4 & $1.5 \times 10^{7}$ & Negative \\
$24 / 01 / 2018$ & A5 & $4.0 \times 10^{7}$ & Negative \\
\hline
\end{tabular}

\section{Samariang Estuary}

\begin{tabular}{cccl}
\hline Sampling date & Sample & $\begin{array}{c}\text { Colony forming unit }(\mathrm{CFU} / \mathrm{ml}) \text { of } \\
\text { yellow colonies }\end{array}$ & PCR assay \\
\hline $16 / 11 / 2017$ & B1 & $1.4 \times 10^{7}$ & Negative \\
$30 / 11 / 2017$ & B2 & $1.0 \times 10^{7}$ & Negative \\
$14 / 12 / 2017$ & B3 & $8.0 \times 10^{7}$ & Negative \\
$28 / 12 / 2017$ & B4 & $2.6 \times 10^{7}$ & Negative \\
$24 / 01 / 2018$ & B5 & $6.0 \times 10^{7}$ & Negative \\
\hline
\end{tabular}

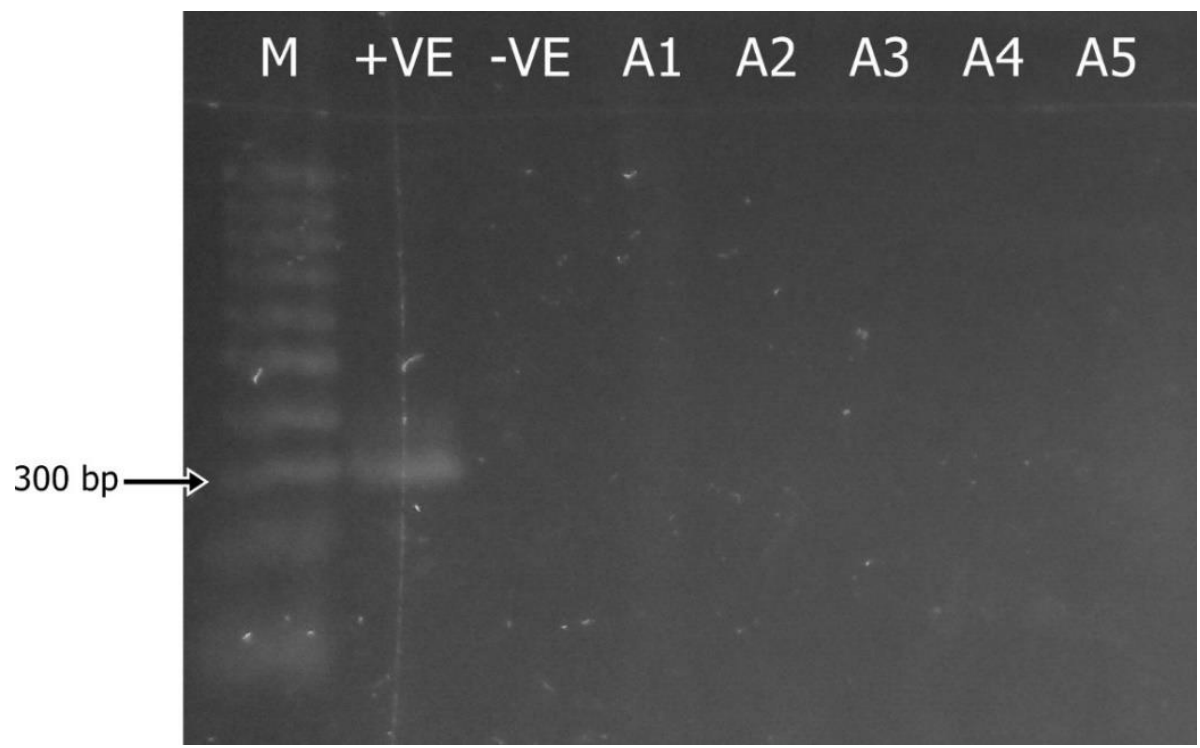

Figure 2. Agarose gel electrophoresis of the ctxA gene of $V$. cholerae (302bp). Lane M: Molecular weight DNA ladder (100 bp); Lane +VE: V. cholerae strain O1 positive control; Lane -VE: Negative control; Lane A1 - A5: PCR amplification for samples from Santubong Estuary. 


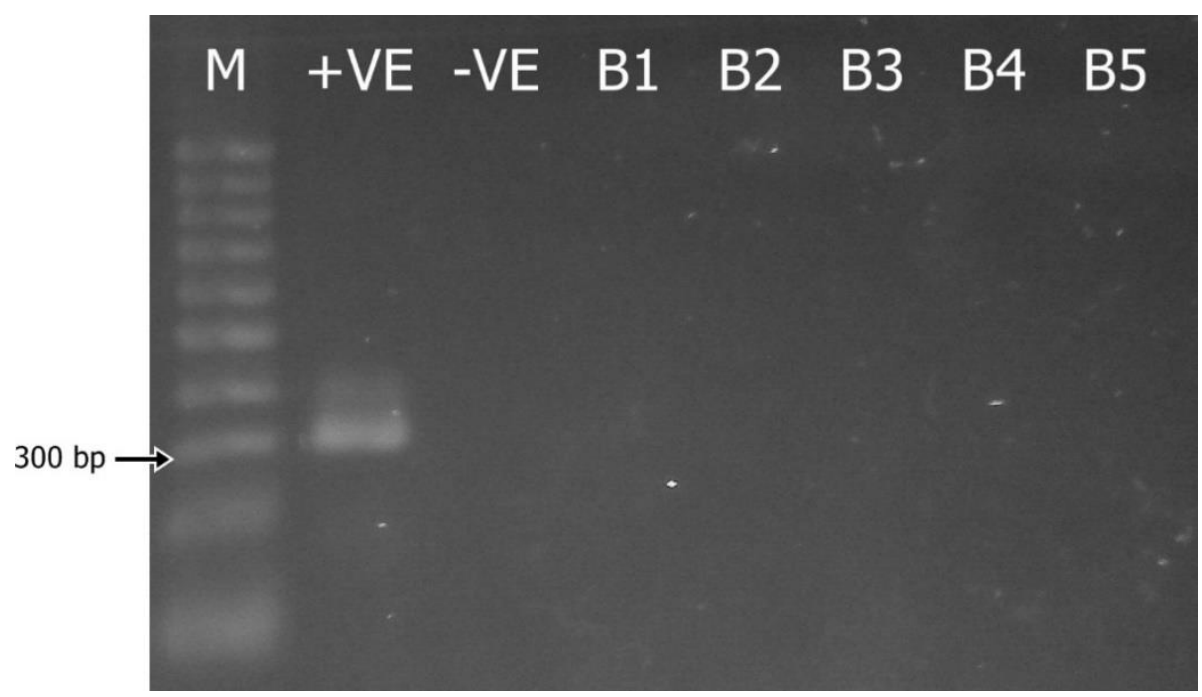

Figure 3. Agarose gel electrophoresis of the $c t x \mathrm{~A}$ gene of $V$. cholerae (302bp). Lane M: Molecular weight DNA ladder (100 bp); Lane +VE: V. cholerae strain O1 positive control; Lane -VE: Negative control; Lane B1 - B5: PCR amplification for samples from Samariang Estuary.

\section{Water Physicochemical Parameters}

The physical parameters such as temperature, salinity and $\mathrm{pH}$ were used to study the association between physical parameters and the presence of $V$. cholerae. The results of water physicochemical parameters of the sampling sites recorded during the five samplings at Santubong and Samariang
Estuaries are shown in Table 3. At Santubong Estuary, temperature of the surface water ranged from $29.2-36.0^{\circ} \mathrm{C}$, salinity ranged from $1.3-3.0$ $\%$ and $\mathrm{pH}$ ranged from $6.3-8.1$, whereas, at Samariang Estuary the physicochemical parameters of surface water samples were temperature that ranged from $27.8-34.5{ }^{\circ} \mathrm{C}$, salinity ranged from $1.3-2.3 \%$ and $\mathrm{pH}$ ranged from 5.9 - 7.6 .

Table 3. Water physicochemical parameters of the phytoplankton samples

\begin{tabular}{ccccc}
\hline \multicolumn{5}{c}{ Santubong Estuary } \\
\hline Date of sampling & Sample & Temperature $\left({ }^{\circ} \mathrm{C}\right)$ & Salinity $(\%)$ & $\mathrm{pH}$ \\
\hline $16 / 11 / 2017$ & A1 & 34.3 & 2.5 & 8.1 \\
$30 / 11 / 2017$ & A2 & 31.8 & 3.0 & 7.6 \\
$14 / 12 / 2017$ & A3 & 33.2 & 1.3 & 6.3 \\
$28 / 12 / 2017$ & A4 & 29.2 & 2.7 & 7.3 \\
$24 / 01 / 2018$ & A5 & 36.0 & 2.2 & 7.1 \\
\hline & & Samariang Estuary & & \\
\hline \multirow{2}{*}{ Date of sampling } & Sample & Temperature $\left({ }^{\circ} \mathrm{C}\right)$ & Salinity $(\%)$ & $\mathrm{pH}$ \\
\hline $16 / 11 / 2017$ & B1 & 30.6 & 1.9 & 7.3 \\
$30 / 11 / 2017$ & B2 & 29.8 & 2.3 & 6.9 \\
$14 / 12 / 2017$ & B3 & 29.5 & 2.2 & 5.9 \\
$28 / 12 / 2017$ & B4 & 27.8 & 2.2 & 6.8 \\
$24 / 01 / 2018$ & B5 & 34.5 & 1.3 & 7.6 \\
\hline
\end{tabular}




\section{DISCUSSION}

Bacterial Enumeration and Detection of $\boldsymbol{V}$. cholerae Targeting the Virulence Cholera Enterotoxin Subunit A (ctxA) Gene

The detection of virulence cholera enterotoxin subunit $A(\operatorname{ctx} A)$ gene, that is only conserved in toxigenic $V$. cholerae (i.e. cholera-toxin producing), by utilising PCR assay is useful to differentiate toxigenic and non-toxigenic $V$. cholerae strains. In this study, no samples from Santubong and Samariang Estuaries were contaminated with cholera toxin-producing $V$. cholerae. The discrepancy of colonies growing on TCBS agar and the finding from PCR assay might indicate the presence of non-toxigenic $V$. cholerae (Lipp et al., 2003) or other noncholera Vibrio species (e.g. V. alginolyticus, $V$. fluvialis, V. furnissii) (USFDA, 2004) which may still cause infections in humans.

Based on previous studies in Sarawak such as by Norazah et al. (2001) found $V$. cholerae $\mathrm{O} 1$ in eight out of 80 samples $(10 \%)$ upon an outbreak in Daro and Bintulu. Afterwards, Radu et al. (2002) reported 33 isolates of $V$. cholerae $\mathrm{O} 1$ were linked to an outbreak in Miri. In an earlier study by Benjamin et al. (2005), 1,672 people in Sarawak were infected with $V$. cholerae from 1994 - 2003. In comparison, this study did not obtain any CT-producing isolates.

In retrospect of India subcontinent being cholera endemic, the negative finding of CTproducing $V$. cholerae in this study showed that the water at both estuaries did not receive (or with low level) of human waste contamination (Jiang et al., 2003). The absence of this event (i.e. human waste contamination) may explain the low circulation of the virulence gene among environmental strains. Besides, it could also be low predation of CTX $\varphi$ in the environmental strains that may cause emergence of new toxigenic $V$. cholerae by horizontal gene transfer (Faruque \& Mekalanos, 2012).

Association Between Selected Physicochemical Parameters (pH, Temperature and Salinity) and the Occurrence of $V$. Cholerae in Sampled Phytoplankton

In this study, the physicochemical parameters recorded in all surface water samples of both
Santubong and Samariang Estuaries indicated favourable condition for the distribution of $V$. cholerae in the environment. In natural habitat, $V$. cholerae prefers salinity from the range of 2 to $20 \%$ and temperature between 20 and $35^{\circ} \mathrm{C}$ (Janda et al., 1988). There was no association of $\mathrm{pH}$ on the presence of $V$. cholerae in the environment. Nevertheless, the presence of plankton in the surface water may provide vital support for population of $V$. cholerae especially during unfavourable conditions such as low salinity which may lead to their existence in the "free living" state (Neogi et al., 2012). These association is also supported by Lutz et al. (2013) mentioning that the presence of Vibrio spp. in the environment is associated with the salinity, temperature, as well as zooplankton and phytoplankton.

Based on Table 3, the average physicochemical parameters of surface water samples from Santubong Estuary were more ideal for the presence of $V$. cholerae compared to Samariang Estuary. However, the number of variable yellow colonies appeared on the TCBS agar was lower in Santubong Estuary compared to Samariang Estuary. This could be due to the habitat of the surrounding Samariang Estuary that is surrounded with mangrove forests. Mangroves are environments naturally rich in chitin and the degradation of chitinous and mucilaginous parts of plankton by certain enzymes provides nutrients for survival of V. cholerae (Neogi et al., 2012).

\section{CONCLUSION}

This is the first study investigating the presence of cholera-producing Vibrio cholerae in phytoplankton in Sarawak. The absence of the toxigenic $V$. cholerae in all samples somehow still highlights the presence of other non-CTproducing Vibrio cholerae strains and noncholerae Vibrio species that is still indisputable, that this study did not perform on such detections. As Santubong and Samariang Estuaries are local tourism places, the risks should not be underestimated. Further researches on the presence Vibrio spp. in phytoplankton need to be conducted and evaluated frequently according to the monsoon season in Malaysia.

\section{ACKNOWLEDGEMENTS}

The authors would like to acknowledge the postgraduates from Resource Biotechnology and Aquatic Resource Science \& Management Programmes, Faculty of Resource Science and Technology, UNIMAS, for their assistances. 


\section{REFERENCES}

Alam, M.J., Miyoshi, S.I. \& Shinoda, S. (2003). Studies on pathogenic Vibrio parahaemolyticus during warm weather season in the Seto Inland Sea, Japan. Environmental Microbiology, 5: 706710 .

Benjamin, P.G., Gunsalam, J.W., Radu, S., Napis, S., Bakar, F.A., Beon, M., Benjamin, A., Dumba, C.W., Sengol, S., Mansur, F., Jeffrey, R., Nakaguchi, Y. \& Nishibuchi M. (2005). Factors associated with emergence and spread of cholera epidemics and its control in Sarawak, Malaysia between 1994 and 2003. Japanese Journal of Southeast Asian Studies, 43(2): 109-140.

Bilung, L.M., Radu, S., Bahaman, A.R., Rahim, R.A., Napis, S., Wong, M.C.V.L., Tanil, G.B. \& Nishibuchi, M. (2005). Detection of Vibrio parahaemolyticus in cockle (Anadara granosa) by PCR. FEMS Microbiology Letters, 252(1): 8588.

Broeck, D.V., Horvath, C. \& De Wolf, M.J. (2007). Vibrio cholerae: cholera toxin. The International Journal of Biochemistry \& Cell Biology, 39(10): 1771-1775.

Cavallo, R.A. \& Stabili, L. (2002). Presence of vibrios in seawater and Mytilus gallaprovincialis (Lam.) from Mar Piccolo of Taranto (Ionian Sea). Water Research, 36 (15): 3719-3726.

Dutta, D., Chowdhury, G., Pazhani, G.P., Guin, S., Dutta, S., Ghosh, S., Rajendran, K., Nandy, R.K., Mukhopadhyay, A.K., Bhattacharya, M.K., Mitra, U., Takeda, Y., Nair, G.B. \& Ramamurthy, T. (2013). Vibrio cholerae non-O1, non-O139 serogroups and cholera-like diarrhea, Kolkata, India. Emerging Infectious Diseases, 19(3): 464.

Faruque, S.M. \& Mekalanos, J.J. (2012). Phagebacterial interactions in the evolution of toxigenic Vibrio cholerae. Virulence, 3(7): 556-565.

Huq, A., Haley, B.J., Taviani, E., Chen, A., Hasan, N.A., \& Colwell, R.R. (2012). Detection, isolation, and identification of Vibrio cholerae from the environment. Current Protocols in Microbiology, 26(1): 6A-5.

Janda, J.M., Powers, C., Bryant, R.G., \& Abbott, S.L. (1988). Perspectives on the epidemiology and pathogenesis of clinically significant Vibrio spp. American Society for Microbiology, 1(3): 245-267.
Jiang, S., Chu, W. \& Fu, W. (2003). Prevalence of cholera toxin genes (ctxA and zot) among nonO1/O139 Vibrio cholerae strains from Newport Bay, California. Applied and Environmental Microbiology, 69(12): 7541-7544.

Lipp, E.K., Rivera, I.N., Gil, A.I., Espeland, E.M., Choopun, N., Louis, V.R., Russek-Cohen, E., Huq A. \& Colwell, R.R. (2003). Direct detection of Vibrio cholerae and $c t x A$ in Peruvian coastal water and plankton by PCR. Applied and Environmental Microbiology, 69(6): 3676-3680.

Lutz, C., Erken, M., Noorian, P., Sun, S. \& McDougald, D. (2013). Environmental reservoirs and mechanisms of persistence of Vibrio cholerae. Frontiers in Microbiology, 4: 375.

Nandi, B., Nandy, R.K., Mukhopadhyay, S., Nair, G.B., Shimada, T. \& Ghose, A.C. (2000). Rapid method for species-specific identification of Vibrio cholerae using primers targeted to the gene of outer membrane protein OmpW. Journal of Clinical Microbiology, 38(11):4145-4151.

Neogi, S.B., Islam, M.S., Nair, G.B., Yamasaki, S. \& Lara, R.J. (2012). Occurrence and distribution of plankton-associated and free-living toxigenic Vibrio cholerae in a tropical estuary of a cholera endemic zone. Wetlands Ecology and Management, 20(3): 271-285.

Norazah, A., Zainuldin, M.T., Kamel, A.G., Kamaliah, M.N. \& Taha, A.M. (2001). Detection of Vibrio cholerae 01 from aquatic environment in Sarawak. The Medical Journal of Malaysia, 56(1): 4-9.

Peterson, O., Asplund, M., Karunasagar, I., \& Godhe, A. (2010). Phytoplankton community composition and diversity effects on the growth of marine Vibrio bacteria. In Pagou, P., \& Hallengraeff, G. (Eds.), International society for the study of harmful algae and intergovernmental oceanographic commission of UNESCO 2013: Proceedings of the $14^{\text {th }}$ International Conference on Harmful Algae (pp 147-149). Crete: Hersonissos.

Radu, S., Vincent, M., Apun, K., Rahim, R.A., Benjamin, P.G. \& Rusul, G. (2002). Molecular characterization of Vibrio cholerae O1 outbreak strains in Miri, Sarawak (Malaysia). Acta Tropica, 83(2): 169-176.

Reidl, J. \& Klose, K.E. (2002). Vibrio cholerae and cholera: out of the water and into the host. FEMS Microbiology Reviews, 26(2): 125-139. 
Sharma, A. \& Chaturvedi, A.N. (2006). Prevalence of virulence genes (ctxA, stn, OmpW and tcpA) among non-O1 Vibrio cholerae isolated from fresh water environment. International Journal of Hygiene and Environmental Health, 209(6): 521-526.

Smith, A.C. \& Hussey, M.A. (2005). Gram staining protocols. American Society for Microbiology. http://www.asmscience.org/content/education/protocol/ protocol.2886. Downloaded on 3 May 2019.

Tuney, I. \& Maroulakis, M. (2014). Phytoplankton sampling methods. Crete, Greece: Environmental Protection Management \& Economics (ENVECO S.A.).
U.S Food \& Drug, USFDA (2004). Bacteriological Analytical Manual Chapter 9 Vibrio. https://www.fda.gov/food/foodscienceresearch/lab oratorymethods/ucm070830.htm. Downloaded 2 February 2019.

Vincent, M., Lai, L.S., Ng, L.T. \& Apun, K. (2014). Application of PCR-based DNA fingerprinting techniques for the genetic differentiation of Vibrio cholerae Non-01/Non 0139 isolates form Kuching, Sarawak. Borneo Journal of Resource Science and Technology, 4(2): 21-34. 